\title{
Isolation of homogenous ribosome-nascent-chain complexes from coupled cell-free transcription- translation system
}

\section{Gong Zhang}

Biochemistry, Inst. of Biochem. and Biology, Univ. Potsdam, 14476 Potsdam, Germany.

\section{Zoya Ignatova}

Biochemistry, Inst. of Biochem. and Biology, Univ. Potsdam, 14476 Potsdam, Germany.

\section{Method Article}

Keywords: cell-free transciption-translation, E. coli, nascent chains, translation

Posted Date: February 16th, 2009

DOI: https://doi.org/10.1038/nprot.2009.47

License: (c) (1) This work is licensed under a Creative Commons Attribution 4.0 International License.

Read Full License 


\section{Abstract}

\section{Introduction}

Recent studies have made some progress in tracking the conformation of the nascent chains ${ }^{1-3}$; however the earliest steps of folding _in vivo_ \(while chain synthesis is underway) remain unclear. This is in part due to a lack of experimental methods to produce stable ribosome-nascent chain complexes with uniform length of the nascent chains. Translation mixtures usually contain heterogeneous fraction of ribosomes with various lengths of the peptide chains due to re-initiation of the translation; this hinders the precise assessment of the conformation of the nascent chains. Here, we describe a detailed procedure to produce homogeneous fractions of ribosome-nascent-chain complexes with defined length of the stalled peptides.

\section{Reagents}

- coupled transcription-translation_E. coli_cell-free system \(RTS100_E. coli_ HY kit; Roche Applied Science) - T7 RiboMAX_in vitro_transcription kit \(Promega) - Total RNA isolation kit \(Promega) - ${ }^{35}$ Smethionine $\backslash(>1000 \mathrm{Ci} / \mathrm{mM}$, Amersham $)$ - Amino acid mix $\backslash(1 \mathrm{mM}$ each amino acid, Met-depleted, provided by manufacturer, Roche Applied Science) - $3.75 \mathrm{mM}$ aurintricarboxylic acid $\backslash$ (Sigma) dissolved in methanol - SDS-loading buffer: $3.79 \mathrm{~g}$ Tris, $1 \mathrm{~g}$ SDS, $0.5 \mathrm{~g}$ bromophenol blue, $50 \mathrm{ml}$ glycerol, add water to $100 \mathrm{ml}, \mathrm{pH}=6.8$

\section{Equipment}

Temperature block \(Eppendorf) Ultracentrifuge \(Beckman) with TLA120.2 rotor SDS-PAGE equipment SDS-gel dryer $\backslash$ (Biorad) Phosphoimager $\backslash$ (Fujifilm)

\section{Procedure}

1. Dissolve the components of the coupled transcription-translation_E. coli_cell-free system $\backslash$ (RTS100 _E. coli_ HY kit) as follows: a. The amino acid mixture in $240 \mu$ of reconstitution buffer $\backslash$ (provided by manufacturer). Note that here we used methionine-depleted amino acid mix. b. The _E. coli_lysate in 360 $\mu \mathrm{l}$ of reconstitution buffer. c. The reaction mixture in $300 \mu \mathrm{l}$ of reconstitution buffer. 2 . Mix the two components $\backslash(\mathrm{b}$ and $\mathrm{c})$, aliquot them into $100 \mu \mathrm{l}$, and freeze immediately in liquid nitrogen. The 2x master mix can be stored in $-80^{\circ} \mathrm{C}$ for 3 months. Aliquot the amino acid mix in $50 \mu \mathrm{l}$ and store also at $-80^{\circ} \mathrm{C}$. 3 . Subclone your gene of interest or truncations of it into pIVEX vector $\backslash$ (Roche Applied Science) or in any T7-promoter based vectors $\backslash($ e.g., pET-system). The coding sequence of the protein of interest or its truncations should be extended C-terminally by the SecM-sequence $\backslash$ (DYAHFTPQAKFxxxxWIxxxxGIRAGP) ${ }^{4}$ in order to stably stall the nascent chains on the ribosomes. The SecM should be linked to the protein or its truncations by a Gly-Ser-rich linker $\backslash$ (preferably 13 amino acids long), which will ensure that the complete full-length nascent chain of interest is outside the ribosomal 
tunnel. 4. Add $2.5 \mathrm{ng}$ plasmid DNA to $9.5 \mu \mathrm{l}$ aliquot of the 2 -master mix $\backslash$ (thawed on ice) and adjust the final volume to $20.5 \mu \mathrm{l}$ with sterile RNAse-free water. Transcribe for $15 \mathrm{~min}$ at $30^{\circ} \mathrm{C}$. Perform control reaction under identical conditions using an empty plasmid without an insert. Alternatively, the transcription can be performed separately using _in vitro_transcription system \(Promega): mRNA is transcribed according to manufacturer instructions with T7 RiboMAX_in vitro_transcription kit and purified thereafter with total RNA isolation kit. $2 \mu$ purified mRNA from one transcription reaction is added to $9.5 \mu \mathrm{l}$ aliquot of the $2 \mathrm{x}$-master mix and the final volume is adjusted to $20.5 \mu \mathrm{l}$ with sterile RNAse-free water. 5 . Initiate translation by adding $1 \mu \mathrm{l} 0.6 \mathrm{mCi}^{-\mathrm{ml}^{-1}}{ }^{35} \mathrm{~S}$-methionine and $3 \mu \mathrm{l}$ of the amino acid mix. 6 . After 15 seconds add $0.5 \mu \mathrm{l}$ aurintricarboxylic acid to $75 \mu \mathrm{M}$ final concentration to synchronize the reaction ${ }^{5}$, and incubate further at $30^{\circ} \mathrm{C}$. Alternatively, the translation reaction can be performed from 24 ${ }^{\circ} \mathrm{C}-37^{\circ} \mathrm{C}$ if necessary, however the optimal translation temperature for RTS100_E. coli_ HY $\backslash$ (suggested also by the manufacturer) is $30^{\circ} \mathrm{C}$. 7. Set the time for translation according to the length of the gene of interest, given that the rate of translation at $30^{\circ} \mathrm{C}$ is $43-54$ amino acid $/ \mathrm{min}$, at $37^{\circ} \mathrm{C}-130-140$ amino acids/min, and at $24^{\circ} \mathrm{C}-20-25$ amino acids/min. 8. Stop the reaction by immediate chilling on ice ${ }^{6}$; keep an aliquot of $5 \mu \mathrm{l}$ for further SDS-PAGE analysis. 9. Layer $20 \mu \mathrm{l}$ of the reaction mixture on a $900 \mu \mathrm{l}$ of 0.5 $\mathrm{M}$ sucrose in $200 \mathrm{mM}$ HEPES buffer $\mathrm{pH} 7.5$, containing $15 \mathrm{mM} \mathrm{MgCl}_{2}$ and $100 \mathrm{mM} \mathrm{KOAc}$ and pelleted by ultracentrifugation for $20 \mathrm{~min}$ at $4{ }^{\circ} \mathrm{C} \backslash($ TLA120.2 rotor, $120000 \mathrm{rpm})$. 10 . Carefully remove the whole supernatant and gently resuspended the pellet in $20 \mu \mathrm{l}$ of $200 \mathrm{mM}$ HEPES buffer $\mathrm{pH} 7.5$, containing 15 $\mathrm{mM} \mathrm{MgCl}_{2}$ and $100 \mathrm{mM} \mathrm{KOAc.} \mathrm{11.} \mathrm{Mix} 5 \mu \mathrm{l}$ aliquot with the $5 \mu \mathrm{l} \mathrm{SDS-loading} \mathrm{buffer,} \mathrm{heat} \mathrm{at} 95^{\circ} \mathrm{C}$ for 3 min and load onto $12 \%$ SDS-PAGE. The aliquot from step 8 should be identically processed and loaded on the same gel. 12. Dry the gel using vacuum gel dryer and visualize the translation pattern by phosphoimaging. Note that due to the low concentration of the nascent chains, an overnight exposure at low temperature $\backslash\left(-20^{\circ} \mathrm{C}\right)$ in the lead-shielded cassette is recommended.

\section{Timing}

Preparation of buffers and SDS-gel - 4-5 hours $\backslash$ (time is variable depending on the experience) Translation reaction and ultracentrifugation - 1-2 hours SDS-electrophoresis and drying of the gel - 4-5 hours Exposure in the phosphoimager - over night

\section{Critical Steps}

Translation \(steps 3-7) is crucial. The yields might be first analyzed on SDS-PAGE before proceeding with the next steps. Perform all the reaction post-translation \(steps 7-9) to decrease the drop-off of the nascent chains.

\section{Troubleshooting}

No yields in the transcrition-translation reaction: Use preferably pIVEX vectors for the expression. Note that the RTS100_E. coli_ HY system is optimized for the pIVEX vectors and with other T7-vectors lower 
translational yields might be achieved. Low yields in the transcrition-translation reaction: - increase the time of the reaction by $10-15 \%$ as the particular protein might be synthesized with a non-uniform rate of translation through many local attenuations. - increase also the time for transcription to achieve higher starting concentration of mRNA. - perform separate transcription \(step 4) and use higher starting mRNA concentration. - avoid adding any reagents containing glycerol as it might severely reduce the yields of translation reaction.

\section{References}

1. Gilbert, R.J. et al. Three-dimensional structures of translating ribosomes by Cryo-EM._Mol. Cell_**14**, 57-66 \(2004). 2. Hsu, S.T. et al. Structure and dynamics of a ribosome-bound nascent chain by NMR spectroscopy. _Proc. Natl. Acad. Sci. USA_**104**, 16516-16521 \(2007). 3. Johnson, A.E. The cotranslational folding and interactions of nascent protein chains: a new approach using fluorescence resonance energy transfer. _FEBS Lett._ ${ }^{\star * 579 \star \star}$, 916-920 \(2005). 4. Murakami, A., Nakatogawa, H. \& Ito, K. Translation arrest of SecM is essential for the basal and regulated expression of SecA. _Proc. Natl. Acad. Sci. USA_ **101**, 12330-12335 \(2004). 5. Stewart, M.L., Grollman, A.P. \& Huang, M.T.

Aurintricarboxylic acid: inhibitor of initiation of protein synthesis. _Proc. Natl. Acad. Sci. USA_ ${ }^{\star \star 68 * \star}, 97-$ $101 \backslash(1971) .6$. Woolhead, C.A., Johnson, A.E. \& Bernstein, H.D. Translation arrest requires two-way communication between a nascent polypeptide and the ribosome. _Mol. Cell_ ${ }^{\star \star} 22^{\star \star}, 587-598 \backslash(2006)$. 